\title{
THE RESULTS OF ROUTINE PROPHYLAXIS AND TREATMENT OF RICKETS IN WAR-TIME NURSERIES
}

\author{
BY
}

DAVID KRESTIN, M.D., M.R.C.P.

In an earlier paper (Krestin, 1944) it was shown that rickets, although generally of a mild nature, still presented a problem in infant entrants to the wartime nurseries of Preston, since 36 per cent. of those under two years were found to have evidence of past or active disease, and in some of the poorer districts the incidence was considerably higher. Moreover, it was further noted that even when mothers had previously availed themselves of the free distribution of the Ministry of Food cod-liver oil for their babies, the results were still disappointing. Similarly, in a recent widespread survey throughout Great Britain and Ireland published by the Ministry of Health (1944) 73 per cent. of infants with x-ray evidence of rickets were said to have previously received codliver oil or other vitamin D preparation. Since the efficacy of cod-liver oil both in the prophylaxis and the treatment of this disease is now beyond doubt, it is clear that such results could be due only to inadequate dosage or to carelessness and irregularity of administration. It seemed, therefore, of interest to assess the results of the prophylactic use of cod-liver oil and of the therapeutic use both of this and of a more concentrated preparation of vitamin D for active rickets, as used in the routine of the Preston war-time nurseries where the doses and regularity of administration could be assured.

The subjects of this investigation were all unselected infants and children admitted to three residential and ten day nurseries. All were full-term babies. The conditions and diets were fairly uniform and constant in all the nurseries. Infants under six months were fed on a dried or fresh cow's milk. All were examined clinically soon after admission, whilst all under three years and some older children had x-ray films taken of the distal ulna epiphyses. Thereafter, regular clinical examinations were carried out at monthly or shorter intervals. All were again $x$-rayed at the end of six months, and the 'controls' with a small number of the others were $x$-rayed at shorter intervals during this period. More frequent x-ray examinations were not possible owing to the distance of the nurseries from the $x$-ray centre. Chemical investigations of the blood were not practicable.

Three groups were studied, a ' control,' a ' prophylactic' and a 'therapeutic.' The first two were free from all obvious disease or defect on admission, and the third from all disease other than active rickets as determined radiologically.

The cod-liver oil used was that supplied by the Ministry of Food and was ' fortified ' by the addition of calciferol $\left(D_{2}\right)$ so that one drachm contained $700-800$ I.U. of vitamin D. It was given in the pure form in a teaspoon in two divided doses after meals. In the case of infants under six months the initial dose was half a drachm twice daily and this was increased within a week to the full dose stated in table 1. In about 2 or 3 per cent. the oil could not be given owing to refusal on the part of the child, the appearance of skin rashes, or gastro-intestinal upsets. These were then given a more concentrated preparation of vitamin $D$, but are not included in this paper. Those in day nurseries received the doses on six days, and the residents on seven days a week. The concentrated preparation used in some of the 'therapeutic' group was given in a single daily dose and contained 2000 I.U. of vitamin D per c.c.

The observations of the 'control' group were made during a six-months' period from the autumn of 1943 to the early spring of 1944 . Those of the other two groups were made during this period as well as the same period of the previous year. The diets and conditions in the nurseries during these two periods were similar and the climatic conditions much the same. Further, no other method of treatment, such as ultra-violet radiation, was used in these children.

\section{Discussion of results}

Control and prophylactic groups - table 1. In these groups the development of rickets was recognized either by the $x$-ray changes or by the clinical signs. The $\mathrm{x}$-ray manifestations will be considered below, but it should be stated that in early or mild cases no abnormal changes may appear in the lower ulna epiphyses, or they may last for so short a time that they may be missed unless films are taken regularly at brief intervals. After the third month and before the sixth month craniotabes, i.e. areas of asymmetrical softening of the cranial bones limited to the region of the lambdoid suture, was found to be a reliable sign of the disease. After the fourth or fifth month, a well-developed enlargement of the costo-chondral junction of the fifth to the tenth ribs 
TABLE 1

THE PROPHYLAXIS OF RICKETS BY ROUTINE COD-LIVER OIL

\begin{tabular}{|c|c|c|c|c|c|c|c|c|c|c|c|c|c|c|c|c|}
\hline \multirow{3}{*}{ Age group } & \multirow{3}{*}{ 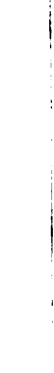 } & \multicolumn{3}{|c|}{ Controls } & \multicolumn{12}{|c|}{ Received cod-liver oil } \\
\hline & & \multirow{2}{*}{ 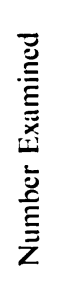 } & \multirow{2}{*}{$\begin{array}{l}\text { Developed } \\
\text { Rickets }\end{array}$} & \multirow{2}{*}{ 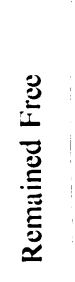 } & \multicolumn{3}{|c|}{$\begin{array}{c}1 \mathrm{drachm} \\
\text { (700-800 I.U. } \\
\text { Vit. D) }\end{array}$} & \multicolumn{3}{|c|}{$\begin{array}{c}2 \text { drachms } \\
\text { (approx. } 1500 \\
\text { I.U. Vit. D) }\end{array}$} & \multicolumn{3}{|c|}{$\begin{array}{l}3 \text { drachms } \\
\text { (approx. 2100 } \\
\text { I.U. Vit. D) }\end{array}$} & \multicolumn{3}{|c|}{$\begin{array}{l}4 \text { drachms } \\
\text { (approx. 3000 } \\
\text { I.U. Vit. D) }\end{array}$} \\
\hline & & & & & 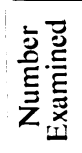 & 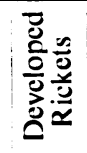 & 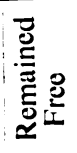 & 总总 & 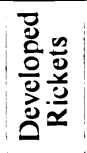 & 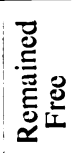 & 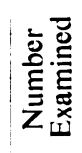 & 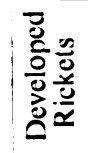 & 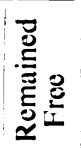 & 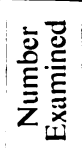 & 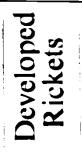 & 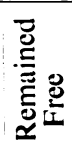 \\
\hline 0 to 6 months & $\bar{i}$ & 44 & $\begin{array}{c}30 \\
(68 \text { per } \\
\text { cent. }) \\
(23 \text { x-ray }\end{array}$ & $\overline{14}$ & 18 & 12 & 6 & 28 & $\begin{array}{c}3 \\
(10 \cdot 7 \\
\text { per } \\
\text { cent. })\end{array}$ & 25 & - & - & - & - & - & - \\
\hline $\begin{array}{l}6 \text { months to } \\
\text { year. }\end{array}$ & 1 & & positive) & & - & - & - & 28 & $\begin{array}{c}2 \\
(7 \\
\text { per } \\
\text { cent. })\end{array}$ & 26 & 15 & 0 & 15 & - & - & - \\
\hline 1 to 2 years & . & 28 & $\begin{array}{c}3 \\
\left(10^{\cdot} \cdot 7\right. \\
\text { per cent. })\end{array}$ & 25 & - & - & - & 55 & $\begin{array}{c}6 \\
(10.9 \\
\text { per } \\
\text { cent. })\end{array}$ & 49 & 11 & 1 & 10 & 44 & 0 & 44 \\
\hline 2 to 3 years & $\cdots$ & 15 & 0 & 15 & - & - & - & 63 & 0 & 63 & - & - & - & 60 & 0 & 60 \\
\hline 3 to 5 years & $\ldots$ & 20 & 0 & 20 & - & - & - & 70 & $\mathbf{0}$ & 70 & - & - & 一 & 56 & 0 & 56 \\
\hline
\end{tabular}

The diagnosis of rickets was based on x-ray and or clinical signs.

was accepted as diagnostic in those children in whom scurvy had been previously eliminated. Moreover, this latter manifestation may persist for weeks or months after the skiagraphic appearances return to normal. Isolated signs, such as delayed closing of the fontanelles, frontal cranial bossing, and bowing of the legs were found to be unreliable criteria. It is hoped to consider the diagnostic value of these signs more fully elsewhere.

A. Control group. These received no vitamin D preparation throughout the six months' period of observation if signs of rickets did not appear, otherwise treatment was started immediately after the appearance of such signs. In all other respects the diets and conditions under which they lived were the same as for those of the other two groups.

It will be seen that in those under one year, thirty of the forty-four (68 per cent.) developed manifestations of rickets, twenty-three of them showing positive $x$-ray changes, and seven clinical signs only.
With the object of determining whether the nature of the diet or the administration of vitamin $\mathrm{D}$ before admission had any influence on these results, a comparison of these data together with the age at the beginning of the investigation is given for the 0-1year group in table 2 .

No importance can be attached to such small figures. Previous vitamin $\mathbf{D}$ administration appears to have had a favourable influence, but age seems to be of most significance in this series, since twelve of the fourteen who remained free were six months or older on admission.

In those between one and two years of age, the drop to 10.7 per cent. in the development of rickets is striking. Schmorl (1909) in his extensive histological study found a considerable reduction in the numbers affected during the second year. Two possible factors may be mentioned in this connection. First, there is the rate of growth with which the development of rickets is closely related. This is

TABLE 2

AGE, TYPE OF FEEDING AND ADMINISTRATION OF VITAMIN D BEFORE ADMISSION TO NURSERIES IN CONTROLS UNDER 12 MONTHS

\begin{tabular}{|c|c|c|c|c|c|c|c|c|c|}
\hline & $\begin{array}{l}\text { Under G } \\
\text { months }\end{array}$ & $\begin{array}{l}\text { Over } 6 \\
\text { months }\end{array}$ & $\begin{array}{l}\text { Number } \\
\text { exam. }\end{array}$ & $\begin{array}{c}\text { Breast } \\
\text { fed }\end{array}$ & $\begin{array}{l}\text { Bottle } \\
\text { fed }\end{array}$ & $\begin{array}{l}\text { Number } \\
\text { exam. }\end{array}$ & $\begin{array}{c}\text { Previous } \\
\text { Vit. D }\end{array}$ & $\begin{array}{l}\text { No } \\
\text { Vit. D }\end{array}$ & $\begin{array}{c}\text { Number } \\
\text { exam. }\end{array}$ \\
\hline Developed rickets & 12 & $\begin{array}{c}18 \\
(60 \text { per } \\
\text { cent.) }\end{array}$ & 30 & 11 & 19 & 30 & $\begin{array}{c}12 \\
\text { (40 per } \\
\text { cent.) }\end{array}$ & 18 & 30 \\
\hline Remained free & 2 & $\begin{array}{c}12 \\
\text { (86 per } \\
\text { cent.) }\end{array}$ & 14 & 4 & 10 & 14 & $\begin{array}{c}8 \\
\text { (57 per } \\
\text { cent.) }\end{array}$ & 6 & 14 \\
\hline
\end{tabular}


rapid during the first twelve months, but slows down considerably during the second year. Second, the change of diet during this period may be of some significance. Up to the fourth month this, in the nurseries, consists of either dried or fresh cows milk, which, according to values given by Fixsen and Roscoe (1937-38, 1939-40), probably contains less than 2 I.U. of vitamin D per $100 \mathrm{gm}$., so that the total daily intake is probably less than 10 to $12 \mathrm{I} . \mathrm{U}$. From the fifth month onwards small additions are made in the process of weaning, and after the twelfth month the child receives a mixed diet including butter, vitaminized margarine, egg yolk and fish. On the basis of the same values a child in its second year will probably receive from 20 to 25 I.U. daily from the food at the nurseries. This, though very much less than the minimum daily requirements of 300 I.U. suggested by Bicknell and Prescott (1942) may however, be sufficient to protect a child, who, for whatever the reason, was able to avoid the disease up to the end of the first year.

Of the children who had reached two years or more at the beginning of the enquiry, none developed rickets.

B. Prophylactic group. During a preliminary observation period a small series of infants under six months were given $1 \mathrm{drachm}(700-800$ I.U.) of cod-liver oil daily. Of these, two-thirds developed rickets. After this period 2 drachms, i.e. approx. $1500 \mathrm{I}$.U. was given to this age group, of whom three out of twenty-eight (10.7 per cent.) developed rickets. Those over six months but not yet twelve months were divided into two series, one receiving 2 drachms (1500 I.U.) and the other 3 drachms (approx. 2100 I.U.) daily. Of twenty-eight of the former, 2 (7 per cent.) developed signs, but all fifteen of the latter group remained free. Thus it would seem that although the equivalent of a daily dose of $1500 \mathrm{I} . \mathrm{U}$. will protect most infants under one year, it is probably safer to give not less than 2000 I.U. This is double the minimum daily dose recommended by Park (1940), and considerably more than the doses suggested by most authorities, including Jeans and Stearns (1935), Mackay (1942) and Bicknell and Prescott (1942).
Children between one and two years were divided into three sub-groups receiving two, three and four drachms daily. Of those receiving four drachms (approx. 3000 I.U.) all remained free; one of the four receiving three drachms developed rickets and six, i.e. 10.9 per cent. of the fifty-five receiving two drachms developed signs of the disorder. The last figure is surprisingly high compared with the controls developing rickets in the same age group, and although the numbers concerned are too small to be of much significance, they suggest that whilst the liability to rickets is not great at this age, those who are liable may require higher doses than during the first year.

As would be expected from the control series, all over 2 years remained free from disease on the doses given.

2. Treatment of rickets table 3. Although experience in these nurseries has shown that craniotabes as defined above may be accepted as reliable evidence of active rickets in infants over three months, the disappearance of this sign at about the sixth month does not constitute proof that healing has occurred. Enlargement of the costo-chondral junctions, the only other reliable clinical sign in infancy, can, however, persist for weeks or even months after activity has ceased. Hence, even though the experienced examiner can often make a correct guess by the firmer and more sharply defined feel of these enlargements that the condition is healed, the only certain means of deciding this matter, in the absence of bio-chemical investigations, is by the radiological examination of the ulna epiphyses. Thus, the diagnosis and the results of treatment referred to in table 3 are all based on x-ray films.

The radiological appearances of active and healing rickets have been fully and clearly described by Wimberger (1923), Hess (1930), and others, and so require no detailed description here. The cases under present consideration are divided into two series: (a) 'mild,' recognized by a fluffiness and fraying of the metaphyses; and (b) 'more severe,' in which these changes were more advanced and accompanied by the typical cupping and broadening of this zone. Healing was recognized by the

TABIE 3

TREATMENT OF RADIOLOGICALLY ACTIVE RICKETS BY COD-LIVER OIL AND A CONCENTRATED VITAMIN D PREPARATION

\begin{tabular}{|c|c|c|c|c|c|c|c|c|c|c|c|c|}
\hline \multirow{3}{*}{ Age group } & \multicolumn{9}{|c|}{ ' Mild' activity; cod-liver oil } & \multirow{2}{*}{\multicolumn{3}{|c|}{$\frac{\text { 'More severe' activity }}{3250 \text { I.U. }}$}} \\
\hline & \multicolumn{3}{|c|}{2 drachms (1500 I.U.) } & \multicolumn{3}{|c|}{3 drachms (2100 I.U.) } & \multicolumn{3}{|c|}{4 drachms (3000 I.U.) } & & & \\
\hline & $\begin{array}{c}\text { Num- } \\
\text { ber } \\
\text { treated }\end{array}$ & $\begin{array}{c}\text { Not } \\
\text { healed }\end{array}$ & Healed & $\begin{array}{l}\text { Num- } \\
\text { ber } \\
\text { treated }\end{array}$ & $\begin{array}{c}\text { Not } \\
\text { healed }\end{array}$ & Healed & $\begin{array}{l}\text { Num- } \\
\text { ber } \\
\text { treated }\end{array}$ & $\begin{array}{c}\text { Not } \\
\text { healed }\end{array}$ & Healed & $\begin{array}{l}\text { Num- } \\
\text { ber } \\
\text { treated }\end{array}$ & $\begin{array}{c}\text { Not } \\
\text { healed }\end{array}$ & Healed \\
\hline $\begin{array}{l}0 \text { to } 6 \text { months } \\
6 \text { months to } 1 \\
\text { year. }\end{array}$ & $\begin{array}{l}15 \\
17\end{array}$ & $\begin{array}{l}\mathbf{0} \\
\mathbf{0}\end{array}$ & $\begin{array}{l}15 \\
17\end{array}$ & - & - & - & - & - & - & $\begin{array}{l}12 \\
11\end{array}$ & $\begin{array}{l}\mathbf{0} \\
\mathbf{0}\end{array}$ & $\begin{array}{l}12 \\
11\end{array}$ \\
\hline $\begin{array}{l}1 \text { to } 2 \text { years.. } \\
2 \text { to } 3 \text { years .. }\end{array}$ & - & - & - & $\begin{array}{l}5 \\
3\end{array}$ & $\begin{array}{l}1 \\
0\end{array}$ & $\begin{array}{l}4 \\
3\end{array}$ & $\begin{array}{l}4 \\
2\end{array}$ & $\begin{array}{l}\mathbf{0} \\
\mathbf{0}\end{array}$ & $\begin{array}{l}4 \\
2\end{array}$ & $\begin{array}{r}16 \\
5\end{array}$ & $\begin{array}{l}\mathbf{0} \\
\mathbf{0}\end{array}$ & $\begin{array}{r}16 \\
5\end{array}$ \\
\hline
\end{tabular}


appearance of a fresh zone of provisional calcification just distal to the old frayed or fluffy one, which became thicker and more sharply defined as the process became more consolidated. Six months after the beginning of treatment most of the radiographs appeared normal. Although in some of the initial films it was not always possible to decide whether healing had actually started, subsequent $x$-rays always settled this doubt. It should be emphasized that in none of the cases here discussed were there signs of advanced clinical disease, such as gross deformity of the chest or bending of the bones.

Those showing ${ }^{\prime}$ mild ' activity were treated with cod-liver oil. During a preliminary trial period a small number in each of the age groups up to three years received 1 drachm (700-800 I.U.) daily, but a high proportion failed to show healing. Thereafter, the daily doses given were as shown in table 3 .

It will be seen that 2 drachms or about 1500 I.U. was sufficient for all those under twelve months. In the one to two year age group one child failed to heal on 3 drachms (2100 I.U.), but the others in this small group and the very small numbers in the two to three year group all healed on 3 and 4 drachms (i.e. 3000 I.U.). Thus in infants under two years there appears to be little difference between the amount of vitamin required for protection and that required for healing a mild or early degree of active rickets.

The ${ }^{-}$more severe ${ }^{\prime}$ series all received a standard dose of $3250 \mathrm{I}$.U. given as a concentrated preparation containing 2000 I.U. per c.c. This was followed by healing in all cases.

It may be mentioned that children showing active disease in the third year all had a rather long history, which suggested that the condition almost certainly began before the age of two years.

Although this article is primarily concerned with full-term and otherwise healthy infants, it may be relevant to stress here the well recognized fact that prematurity and other circumstances may require doses of vitamin $\mathrm{D}$ considerably greater than those discussed above. Thus infants recovering from acute illness or marasmus and so growing relatively fast, and infants receiving thyroid require doses approximately double those given above. Two premature infants under six months both developed rickets on the maximum amount of cod-liver oil it was found possible to administer daily, i.e. 3 drachms (2100 I.U.). Park (1940) considers that such infants require from 5000 to 10,000 I.U. of vitamin D daily, and also draws attention to the danger of lipoid pneumonia following aspiration when large doses of oil are given to feeble infants or those liable to vomiting.

\section{Summary and conclusions}

(1) The results of the routine administration of the Ministry of Food cod-liver oil containing 600-800 I.U. of vitamin $D$ to the drachm, for the protection against rickets, and of this oil and a more concentrated preparation of vitamin D for infants showing radiologically active disease, as used in the Preston war-time nurseries are discussed.

(2) The diagnostic criteria by which the development of the disease was recognized and the manifestations of activity are briefly considered.

(3) In a series of controls under twelve months receiving no protective vitamin, two-thirds developed rickets, whereas in a similar series between one and two years only 10.7 per cent. developed the disorder. Control children over two years all remained free during the six months period of observation.

(4) A daily dose of one drachm of cod-liver oil (600-800 I.U.) failed to protect two-thirds of infants under six months. Two drachms (1500 I.U.) protected most and 3 drachms (2100 I.U.) all the infants under one year. About 11 per cent. of infants between one and two years receiving 2 drachms daily developed rickets, but all remained free on 4 drachms (3000 I.U.).

(5) Infants under one year showing 'mildly' active rickets were all cured on 2 drachms ( 1500 I.U.) of cod-liver oil a day. Those between one and three years appeared to require doses up to 3000 I.U.

All the infants showing a 'more severe' degree of activity responded well to daily doses of $3250 \mathrm{I} . \mathrm{U}$. given as a concentrated preparation.

Thanks are due to Dr. F. A. Sharpe, Medical Officer of Health, for allowing this investigation, and for permission to publish this paper; to Dr. J. Laurie, medical superintendent of Sharoe Green Hospital for the x-ray facilities, and to Miss P. Wright and the Matrons for their valued co-operation.

\section{References}

Bicknell, F., and Prescott, F. (1942). The vitamins in medicine, London.

Fixsen, H. A. B., and Roscoe, M. H. (1937-8). Nutr. Abstr. Rev., 7, 823.

- (1939-40). Ibid., 9, 795.

Hess, A. F. (1930). Rickets and osteomalacia, London.

Jeans, P. C., and Stearns, G. (1935). Proc. Soc. exp. Biol. Med., 32, 1468.

Krestin, D. (1944). Med. Offi., 72, 29.

Mackay, H. M. M. (1942). Practitioner, 148, 25.

Ministry of Health Report (1944). Pub. Health and Med. Subjects, London, No. 92.

Park, E. A. (1940). J. Amer. med. Ass., 115, 370.

Schmorl, S. (1909). Ergebn. inn. Med. Kinderheilk., 4, 403.

Wimberger, H. (1923). Med. Res. Council, Spec. Rep. No. 77 , London. 